\title{
Sandra Sebastián
}

Sandra Sebastín:: Universidad San Carlos de Guatemala, Guatemala / sebastian.sandra@gmail.com Recepción: agosto de 2015

Las fotografias que se presentan en este número de Dixit The photographs displayed on this issue of Dixit were acen en las coberturas de noticias que a diario la foto- origimaly used to inustrate the dall grafa guatemalteca Sandra Sebastián realiza para la as such delivered by Guatemalan photographer Sandra prensa de su pais. Hechos de la vida cotidiana y la politi- Sebastión to the press in her country. Before her lens, ca se mezclan en el lente de esta fotografa con la violen- incidents from everyday life and politics mingle and cia que desde hace mas de medio siglo marca la agenda aiternate with the violent episodes that have characterquerra desde 1996, cuando la firma de un acuerdo de paz Since the peace agreement of 1996 put an end to 36 puso fin a 36 años de conflicto armado interno que deja- vears of civil war resulting in 200000 thousand dead, ron un saldo de 200 mil muertos, 45 mil desaparecidos y 45000 missing people and about 100000 displaced peocerca de 100 mil desplazados. ple, Guatemala has been undergoing a postwar period.

Graduada en Periodismo por las universidades San Carlos A graduate in journalism from two universities (San e Guatemala y Panamericana, y master en Antropologia Carlos de Guatemala and Panamericana) who is a Master Visual por la Universidad de Barcelona, Sandra Sebastian in Visual Anthropology from the University of Barcelono ha expuesto su obra en Guatemala y Estados Unidos, la Sandra Sebastián has exhibited her work in Guatemalo ha publicado en libros y revistas guatemaltecos y extran- and the United States, has published her photographs in jeros y ha obtenido numerosos reconocimientos. Actual-books and reviews both in and outside Guatemaila, and

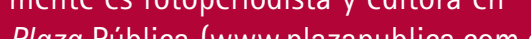

sebastian.sandra@gmail.com has received several awards. At present she is a photo-

journalist and an editor of
Plaza Pública (www.plazapublica.com.gt).

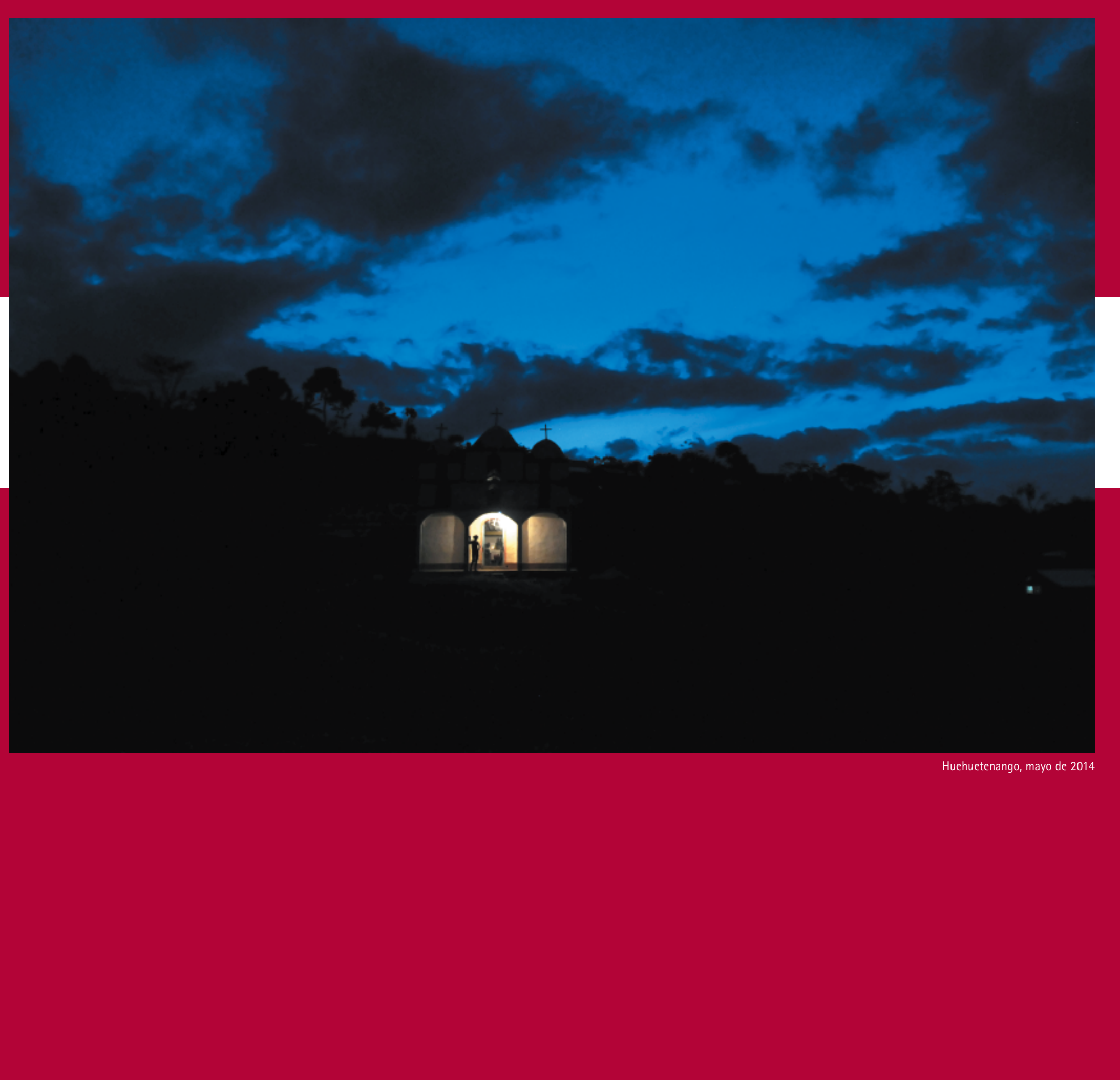



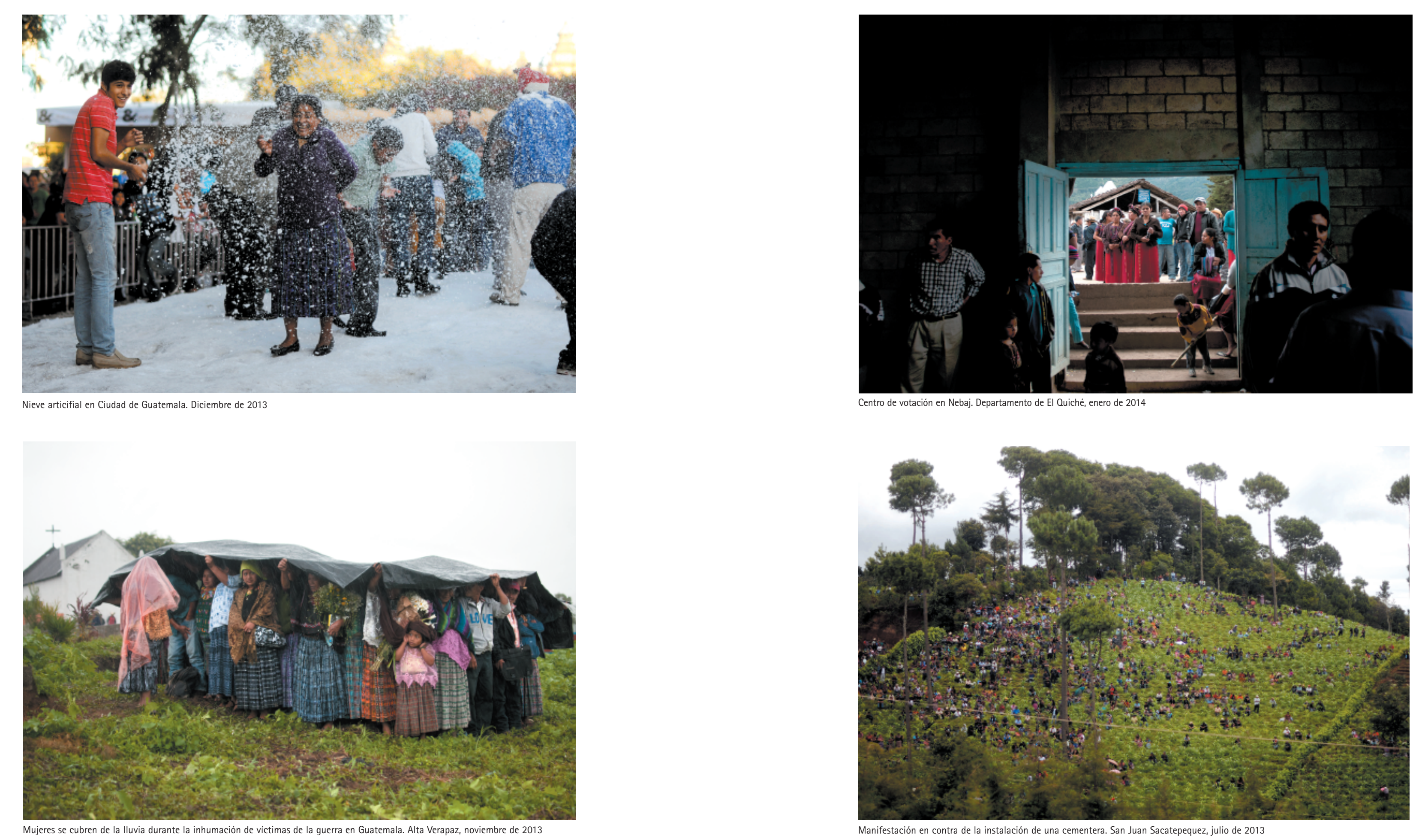

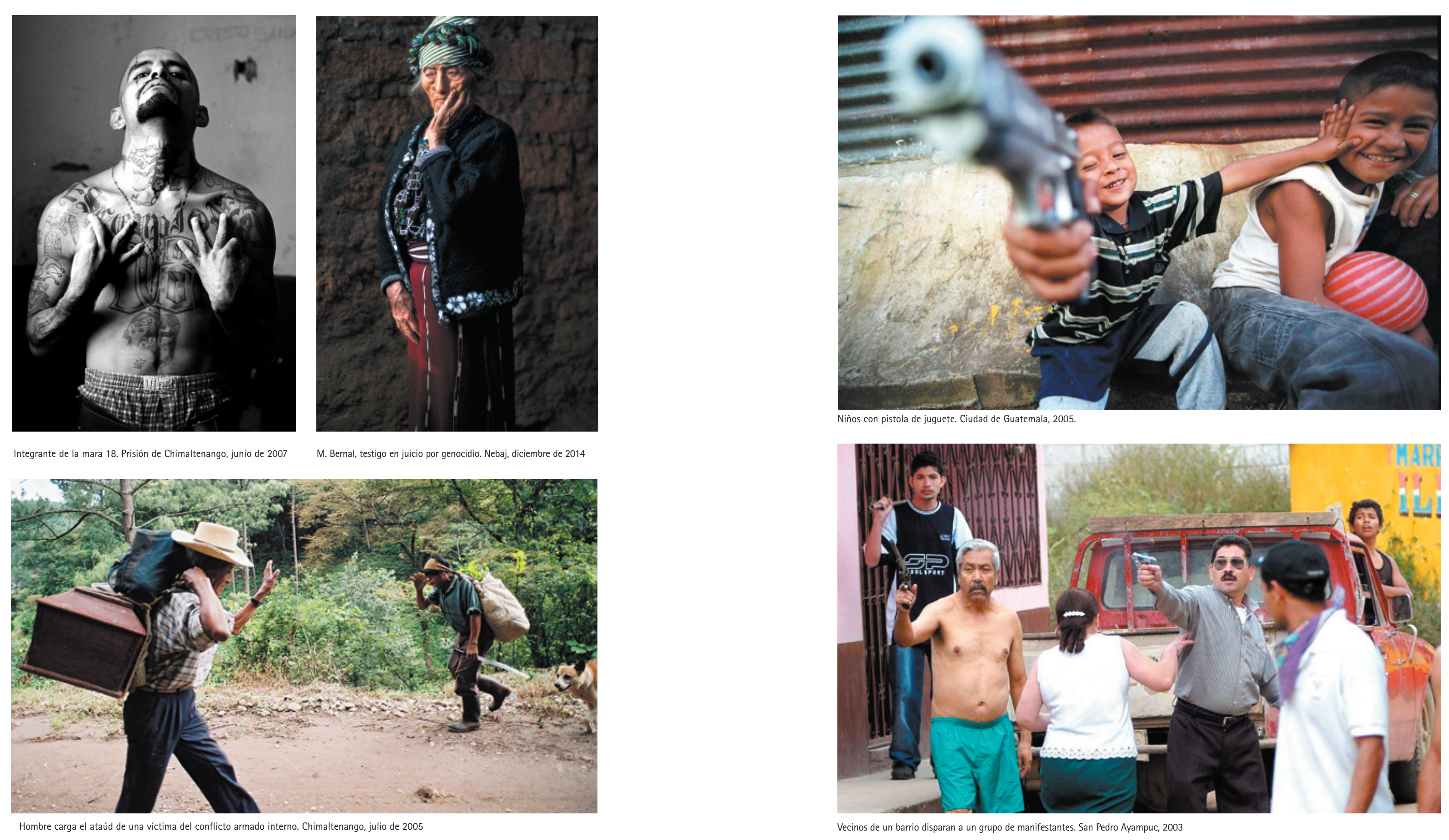